ks. Jerzy Chmiel

\title{
Biblia i liturgia Jana Pawła II. Na 25-lecie pontyfikatu
}

Nie sposób objąć całej działalności Jana Pawła II w dziedzinie Biblii i liturgii - wymaga to długich studiów i obszernego opracowania. Ale można pokusić się o odsłonięcie głównych momentów takiej działalności. Dla ułatwienia podzielmy to na cztery odsłony.

\section{Antepraeparatoria}

Bóg przygotowywał go do trudnego zadania. Zaczęło się od umiłowania słowa, od deklamacji, od teatru szkolnego. Nic dziwnego, że po maturze poszedł na uniwersytecką polonistykę, by kształt słowa rzeźbić dalej. Bóg chciał inaczej: przyszło Karolowi rąbać w kamieniu. Trudne to były chwile w kamieniołomie. Ale nie zrezygnował z rzeźby słowa. Praca w konspiracyjnym teatrze Mieczysława Kotlarczyka dostarczyła mu wiele doświadczenia. A przy tym ten głos - po latach wspomina Danuta Michałowska, słuchaczka recytacji jego własnych wierszy w Domu Katolickim w Krakowie 15 października 1938 roku. Medytacja nad słowem biblijnym przechodzi w iuvenilia jakże bardzo biblijne: Magnificat, Hiob, Jeremiasz, Renesansowy psałterz. Ale ktoś usłyszał jego szept: „Nie, to nie jest to...”, gdy patrzył na program zajęć z filologii. Dlatego duch przesunął się dalej.

\section{Praeparatoria}

Studium teologii w ciężkich okupacyjnych czasach, w konspiracji, w cieniu Księcia Niezłomnego, swojego Metropolity.

Kapłan Karol. Wyjazd na studia zagraniczne. Przede wszystkim Roma antiqua et christiana.

„Myśl jest przestrzenią dziwną”. Po powrocie jako wikariusz zajmuje się śpiewem liturgicznym - to starsza siostra recytacji. A w trudnych, uczonych słowach kazań, konferencji kryją się myśli biblijne.

Teraz osobiste wyznanie. Piszący te słowa jako ministrant w kościele Mariackim - a były to lata pięćdziesiąte ubiegłego stulecia - słyszał po raz 
pierwszy kazanie księdza Karola. Pięknie wypowiedziane (ten głos!), choć trudne, ale zapamiętał z tego kazania jedno zdanie: „Każde słowo Jezusa jest na wagę złota”. To pozostaje na zawsze jakby reguła hermeneutyczna.

Ksiądz doktor pisze wiersze pod pseudonimami, nie chodzi mu o rozgłos: „Non nobis, Domine, non nobis, sed Nomini Tuo da gloriam”. Ile jest tam aluzji biblijnych; choćby Profile Cyrenejczyka! Ale pisze też artykuły, jak ten w „Ruchu Biblijnym i Liturgicznym” (1955) o liturgii Wielkiej Soboty. A w Elementarzu etycznym (,Tygodnik Powszechny”) zasady etyczne są mocno oparte na fundamencie Biblii, choć autor nie widział potrzeby zbytniego przeciążania tekstu siglami.

\section{Magisterium episcopale}

Jako biskup, zrazu pomocniczy krakowski, a potem arcybiskup metropolita, przechodzi na wyższy stopień odpowiedzialności za Biblię i liturgię. Jest to odpowiedzialność pasterza. Zabiera głos na spotkaniach biblistów jako przewodniczący Komisji Episkopatu ds. Nauki Katolickiej i jako biskup podpisujący dokumenty o tematyce liturgicznej.

Wielkim doświadczeniem staje się Sobór Watykański II. To nie tylko wielka próba syntezy (U podstaw odnowy. Studium o realizacji Vaticanum II, Kraków 1972), ale również dzielenie się przeżyciami z pielgrzymki do Ziemi Świętej po II sesji soborowej. Tu już trzeba zajrzeć do Kalendarium życia Karola Wojtyly (II wyd. 2000), ażeby móc wydobyć wszystkie możliwe tematy i aluzje biblijne i liturgiczne. A i tak coś się opuści: żywe słowo, obecność, pamięć o wydarzeniu...

\section{Magisterium Summi Pontificis}

Pamiętny wieczór 16 października 1978 roku. Jan Paweł II z loggii bazyliki Piotrowej: ręce najpierw skrzyżowane na piersi, a potem wyciągnięte ku wszystkim. Następuje pełne otwarcie na bogactwa Biblii i liturgii. Nie próbujmy wyliczać.

Wspomnijmy tylko - obok urzędowych dokumentów magisterium papieskiego - o katechezach środowych, które też należą do tego magisterium. Jakież to bogactwo egzegezy biblijnej, nie akademickiej, lecz pasterskiej, co jedno drugiemu nie przeszkadza. A zatem monumentalne katechezy o małżeństwie i rodzinie, o miłości i o ciele (Mężczyzna i niewiasta stworzyt ich, 1986), oparte na materiałach przygotowywanej jeszcze w Krakowie książki. Napisze potem amerykański teolog i biograf papieża George Weigel, że „być może w XXI wieku teologię ciała uzna się za moment przełomowy nie tylko w teologii katolickiej, lecz również w historii myśli nowożytnej” 
(Świadek nadziei, s. 434). W tych katechezach o teologii ciała papież połączył niejako Biblię z liturgią: „miłość oblubieńcza” staje się liturgią, gdy „mowa ciała”, poprzez doświadczenie sacrum staje się środkiem poznania tego, co Bóg zamyślił dla świata i dla ludzkości „od początku”.

I następne cykle katechez: Wierzę w Boga Ojca Stworzyciela (1987), Wierzę w Jezusa Chrystusa Odkupiciela (1989), Wierzę w Ducha Świętego (1992), Wierzę w Kościót (1996), Maryja w tajemnicy Chrystusa i Kościoła (1998), Wimię Przenajświętszej Trójcy (2000) oraz aktualnie głoszony cykl na temat Psalmów tworzą jakby ośmiotomowy komentarz do Pisma Świętego.

Nie poruszamy - z racji ogromnego materiału - tematów biblijnych w encyklikach papieskich, ale warto zacytować zdanie jednego z wybitnych egzegetów belgijskich Maurice'a Gilberta, który tak się wyraził o encyklice Dives in misericordia: „Jest rzadkością, by encyklika była inspirowana Biblią w takim stopniu, to znaczy zawierała tyle przytoczeń biblijnych".

Mówiąc o słowach, nie zapominajmy o faktach. Jan Paweł II z okazji Wielkiego Jubileuszu Roku 2000 ogłosił list o „pielgrzymowaniu do miejsc związanych z historią zbawienia”. Pragnął odwiedzić Ur, Synaj, Betlejem, Nazaret, Jerozolimę, Damaszek i Ateny. Wielka papieska pielgrzymka od Ur do Aten. Udało mu się to, z wyjątkiem Ur (Irak). Ale papież nie ustąpił: postanowił „przenieść” Ur do Rzymu. 23 lutego 2000 roku w auli Pawła VI miała miejsce pierwsza oficjalna bibliodrama w Watykanie: nabożeństwo Słowa Bożego w scenerii Abrahamowej. Pielgrzym Nieugięty - po raz pierwszy następca Piotra przeszedł śladami Patriarchów, Proroków, Apostołów i samego Jezusa. Tak papieskie czytanie Biblii łączy się z liturgią piegrzymowania.

Trzeba jeszcze zwrócić uwagę na twórczość poetycką papieża, która chociaż nie należy do magisterium papieskiego, ale je odzwierciedla i wyjaśnia. Chodzi tutaj o ostatni utwór poetycki Jana Pawła II Tryptyk rzymski (2003). Doskonały komentarz dał włoski filozof Giovanni Reale („L'Osservatore Romano”, wydanie polskie, 4, 2003). Dlaczego papież odczuł potrzebę pisania poezji na starość? Po pierwsze, czynił to od czasów młodości. Po wtóre, Karol Wojtyła łączy w sobie trzy wielkie siły duchowe: wiarę, filozofię i sztukę. Jest to jakby „kod duszy”. Nie szuka rozgłosu poety, lecz przypomina, że poezja czy sztuka w ogóle należy do spraw wiary i poszukiwania prawdy. Temu pozostaje wierny. Tak jak mówił w 1989 roku do członków Papieskiej Komisji Biblijnej: Pismo Święte jako księga Kościoła jest księgą ludzi.

Autor Tryptyku rzymskiego napisał:

„Jeśli chcesz znaleźć źródło, musisz iść do góry, pod prąd". 
Ze źródła trzeba czerpać wodę czystymi rękami. Jan Paweł II odwołuje się do łacińskiej sentencji z wadowickiego gimnazjum, którą miał przed oczyma jako gimnazjalista:

CASTA PLACENT SUPERIS: PURA CUM VESTE VENITE ET MANIBUS PURIS SUMITE FONTIS AQUAM 